SH. M. Ismael, et al., Characteristic of anchor embedded on concrete under different loading rate, pp.1564 - 1580

\title{
CHARACTERISTIC OF ANCHOR EMBEDDED ON CONCRETE UNDER DIFFERENT LOADING RATE
}

\author{
SH. M. Ismael *, W. M. Khair-Aldien, A. A. Kalil and A. A. Nassr \\ Department of Mechanical Engineering, Faculty of Engineering, Assiut University
}

Received 29 May 2013, accepted 16 July 2013

\begin{abstract}
The effect of anchor embedded length and impact load on the mechanical properties of adhesive concrete joint under different dynamic loading rate was studied [1]. Hopkinson pressure bar was used to apply dynamic load to specimens. Specimens with through hole and embedded anchor lengths of $2.5 \mathrm{~cm}$ and $5 \mathrm{~cm}$ were used in the study. The specimens were hit with strain wave induced using air pressure of 1 and 1.5 bar respectively. The result showed that as the embedded length decrease the maximum load of failure increase also as the pressure increase the specimen tend to absorb most of the wave in the adhesive joint. While as the load wave magnitude decrease the portion of the wave transmits to the concrete part of the specimen causing rupture or cracking of this part increase.
\end{abstract}

Keywords: Epoxy, Anchor, Split Hopkinson Pressure bar, Shock Wave.

\section{Introduction}

Anchor bolts are used commonly in repairing structural concrete [2-5]. In a general use of the term, anchor bolts attach machines to the concrete. Or, more specifically, to anchor something may mean to provide some kind of attachment so that something doesn't slide off, or move with respect to the concrete [6].

The anchor bolt applications generally put the bolt in either tension (bolt trying to pull away) [7] or shear (load parallel to face of concrete) or both. In general, bolts installed in concrete may be either cast in place or post installed. Post-installed anchors are installed after the concrete has cured and is used extensively in maintenance processes. There are two main categories of post-installed anchors, mechanical and adhesive. Both types of anchors are installed into concrete that has already cured. Since the anchors are installed after the concrete has cured this allows for a more flexible design. The adhesive typically consists of a two-part epoxy, polyester or vinylester system which must be mixed prior to installation. Since the load is carried through the bonding agent along the length of the rod, the anchor's capacity is directly related to the embedment depth. Fig.1 [8,9and10] gives a visual representation of how bonding between an adhesive and concrete transfers a load.

Corresponding author.

E-mail address: takashy1980@yahoo.com 
SH. M. Ismael, et al., Characteristic of anchor embedded on concrete under different loading rate, pp. $1564-1580$
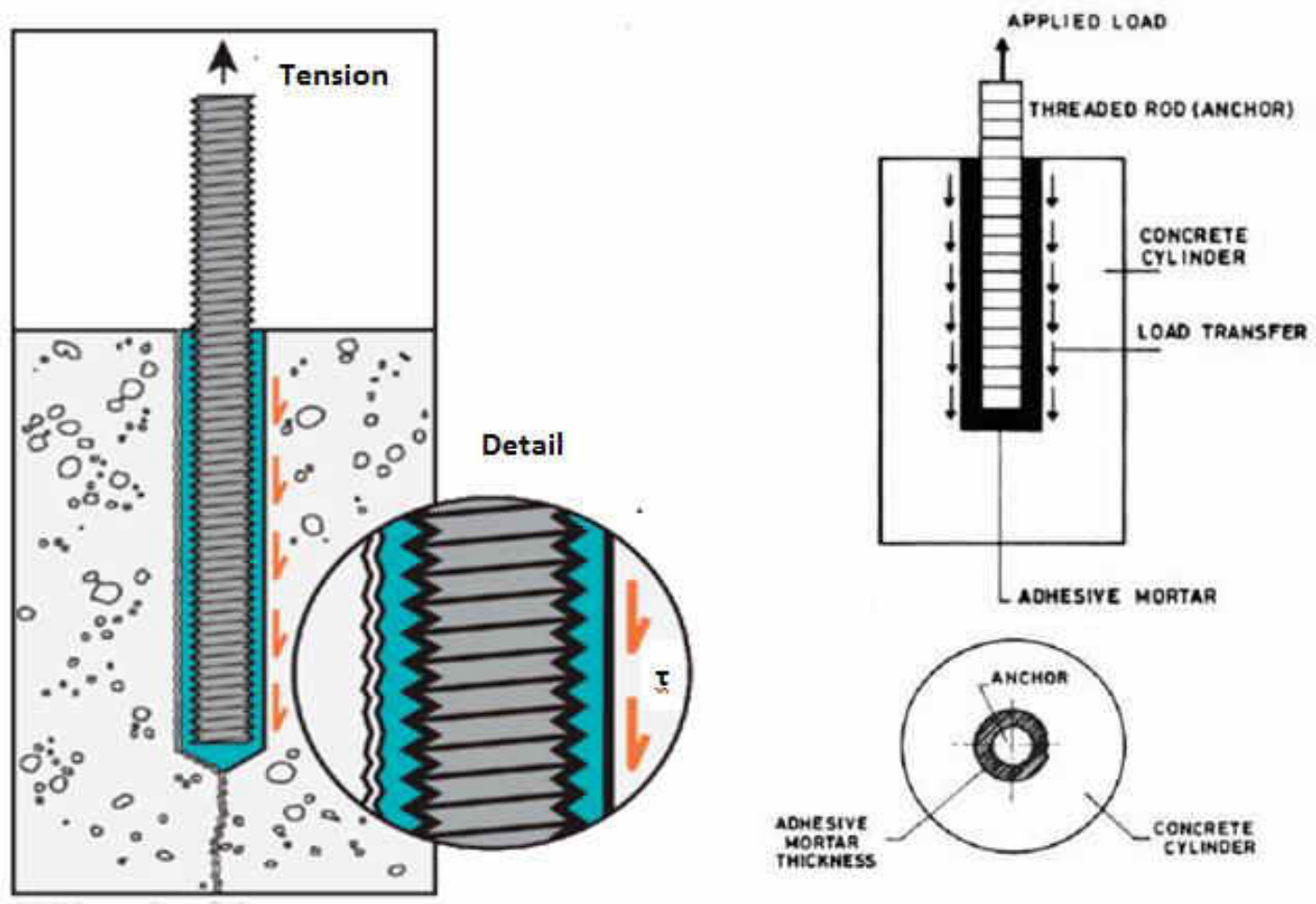

Fig. 1. Mechanism of Load transfer of a bonded anchor

Also, Fig. 1 shows the mechanism for load transfer in bonded anchors $(\tau=$ bond shear stress at the anchor) when the crack propagates through an anchor it will theoretically cause destroyed to one half of the anchor's bond surface area to the concrete .

To ensure better bonding between the mortar and the anchored element, deformed bars or threaded rods are usually used.

The behavior of the adhesive anchor under static tensile force depends on interaction between the following parameter: concrete strength; steel strength; adhesive material strength, interaction strength between adhesive and concrete or interaction strength between adhesive and steel.

The most common anchor failure modes are shown in Fig. 2[11, 12] steel failure mode (same as cast-in and mechanical expansion anchors); concrete breakout(same as cast-in and mechanical expansion anchors); and bond failure (a failure mode similar to bond of a reinforcing bar embedded in concrete).

Journal of Engineering Sciences, Assiut University, Faculty of Engineering, Vol. 41, No. 4, July, 2013,E-mail address: jes@aun.edu.eg 
SH. M. Ismael, et al., Characteristic of anchor embedded on concrete under different loading rate, pp. $1564-1580$

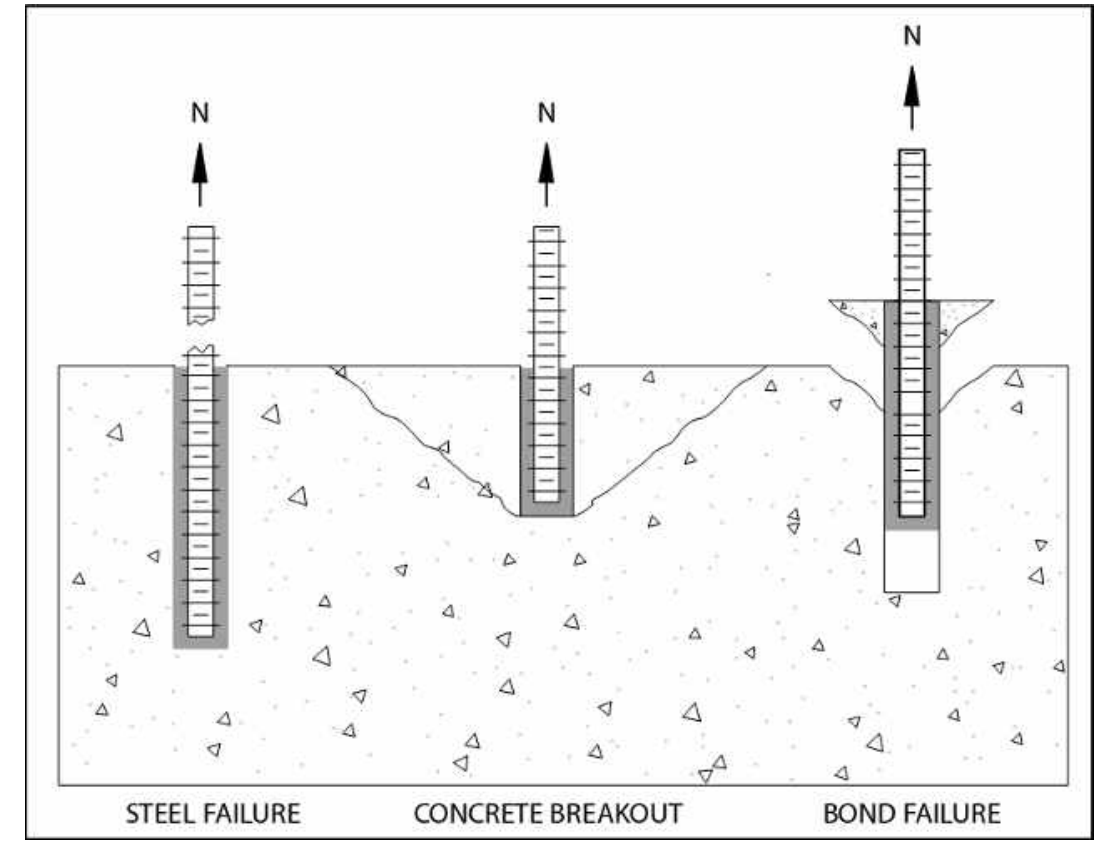

Fig. 1. Failure modes for adhesive anchors

Important of studying the behavior of anchors under static and dynamic load has dramatically increased because of the trend to build more complex architecture designs, the increase of the design loads and altitudes in the modern constructions. Anchors in buildings subjected to high winds and earthquakes need to be specially designed to avoid catastrophic failure.

Universal testing machine was used to determine the failure load under static load condition.

Hopkinson split pressure bar is the only test apparatus that can cover the range of dynamic loading that need to be studied with adequate accuracy because of the nature of its measuring system that element stress wave superposition opportunity. In this work a cylindrical concrete specimen with centered through hole in which a steel bar (corrugated or threaded) installed in it using epoxy for fitting was investigated. The fractured specimens' surfaces were examined carefully to understand the mechanism of failure and the role of each of the compounds in the failure process.

\section{Specimen preparation}

The specimen used in this work consists of three main parts:

1. Concrete cylindrical $100 \mathrm{~mm}$ in diameter and $100 \mathrm{~mm}$ in height with central through hole $12 \mathrm{~mm}$ in diameter as shown in Fig.3.Table 1 shows the used composition of

Journal of Engineering Sciences, Assiut University, Faculty of Engineering, Vol. 41, No. 4, July, 2013,E-mail address: jes@aun.edu.eg 
SH. M. Ismael, et al., Characteristic of anchor embedded on concrete under different loading rate, pp. $1564-1580$

three types of concrete element [13-14]. Compression tests were carried out for standard cubic specimens of each type of concrete. The obtained strength of each type was 185,231 and $311 \mathrm{~kg} / \mathrm{cm}^{2}$.

\section{Table 1.}

Concrete specifications and its compositions

\begin{tabular}{|c|c|c|c|}
\hline & Type1 & Type2 & Type3 \\
\hline Failure stress & $231 \mathrm{~kg} / \mathrm{cm} 2$ & $311 \mathrm{~kg} / \mathrm{cm} 2$ & $180 \mathrm{~kg} / \mathrm{cm} 2$ \\
\hline sand & $23.7 \mathrm{~kg}$ & $23.22 \mathrm{~kg}$ & $24.5 \mathrm{~kg}$ \\
\hline water & $5.55 \mathrm{~L}$ & $6 \mathrm{~L}$ & $6 \mathrm{~L}$ \\
\hline grave & $35.58 \mathrm{~kg}$ & $34.8 \mathrm{~kg}$ & $36.7 \mathrm{~kg}$ \\
\hline cement & $9 \mathrm{~kg}$ & $10.5 \mathrm{~kg}$ & $7.5 \mathrm{~kg}$ \\
\hline
\end{tabular}
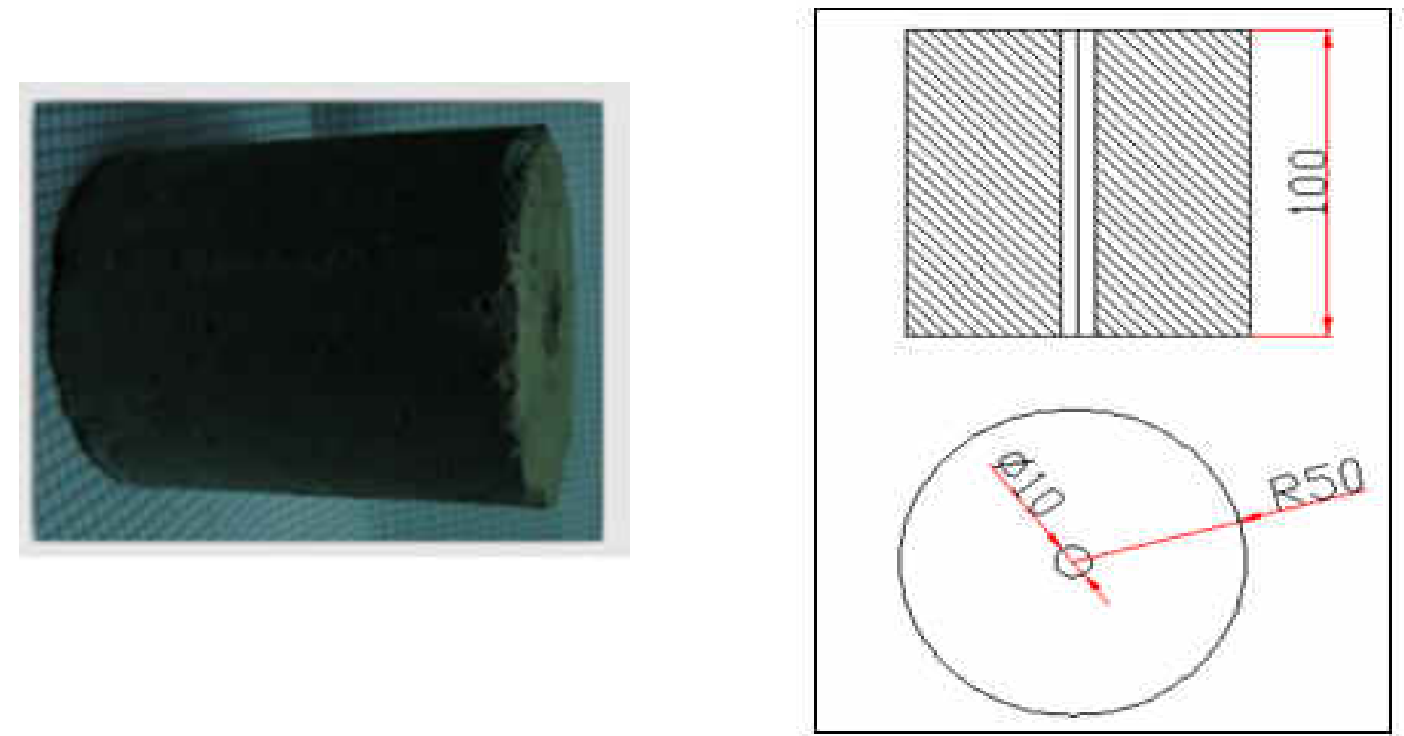

Fig. 3. Concrete block sample

2. Commercial mild steel threaded bolt $10 \mathrm{~mm}$ in diameter with concrete impeded lengths of $(2.5 \mathrm{~cm}$ and $5 \mathrm{~cm})$ respectively.

3. Epoxy type (KEMAPOXYM 165) adhesive material with the following specifications that shown in Table2 and Fig.4 was used [15-17].

Journal of Engineering Sciences, Assiut University, Faculty of Engineering, Vol. 41, No. 4, July, 2013,E-mail address: jes@aun.edu.eg 
SH. M. Ismael, et al., Characteristic of anchor embedded on concrete under different loading rate, pp. $1564-1580$

\section{Table 2.}

Kemapoxym165 Specifications

\begin{tabular}{|c|c|}
\hline Parameters & Values \\
\hline Firm particles & $100 \%$ \\
\hline Density & $1.75 \mathrm{~kg} / \mathrm{m} 3$ \\
\hline Color & White, gray and colored \\
\hline Mixing ratio & $12 \mathrm{~A}: 1 \mathrm{~B}$ \\
\hline Processing time & 30 min. @ $200 \mathrm{C}$ \\
\hline Final strength & After 7 days @ $200 \mathrm{C}$ \\
\hline Compressive strength & CA. $600 \mathrm{~kg} / \mathrm{cm} 2$ \\
\hline Bending strength & CA. $250 \mathrm{~kg} / \mathrm{cm} 2$ \\
\hline Adhesive strength on concrete & more than $25 \mathrm{~kg} / \mathrm{cm} 2$ (cracks in concrete) \\
\hline
\end{tabular}

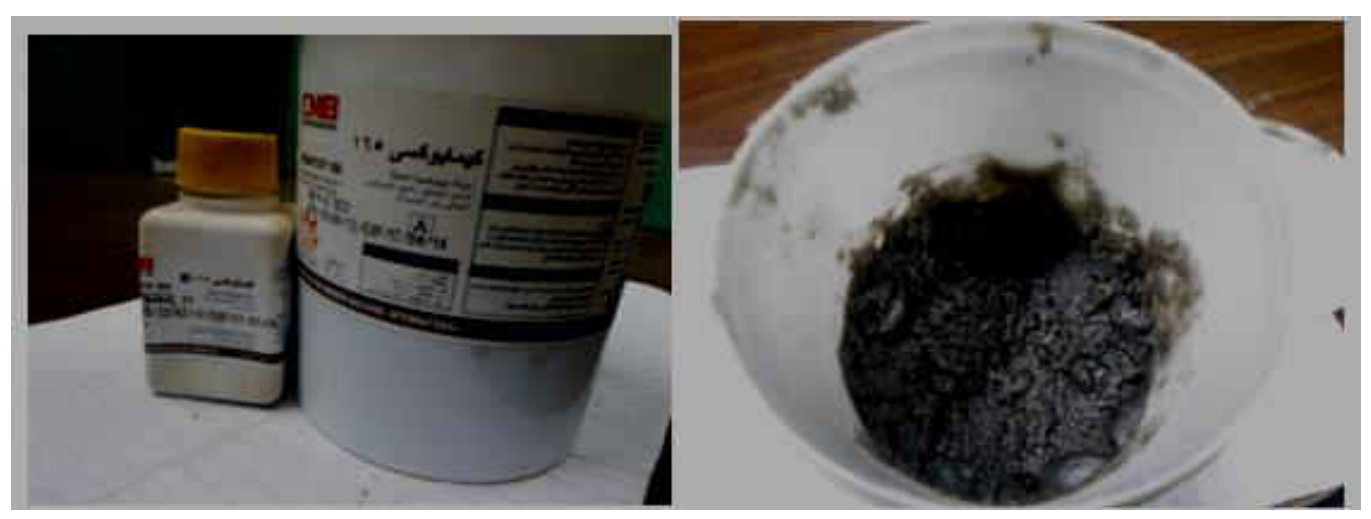

Fig. 4. Kemapoxym165

Specimens were prepared as follows:

- The concrete elements were mixed in concrete mixer and poured in a steel mold having the same dimension of sample. Steel bar of $10 \mathrm{~mm}$ diameter was used to make a center hole in the sample as shown in Fig.5 the steel bar is to be removed before the concrete fully cured after 24 hour.

- The specimens were immersed in water for 28 days.

Journal of Engineering Sciences, Assiut University, Faculty of Engineering, Vol. 41, No. 4, July, 2013,E-mail address: jes@aun.edu.eg 
SH. M. Ismael, et al., Characteristic of anchor embedded on concrete under different loading rate, pp. $1564-1580$
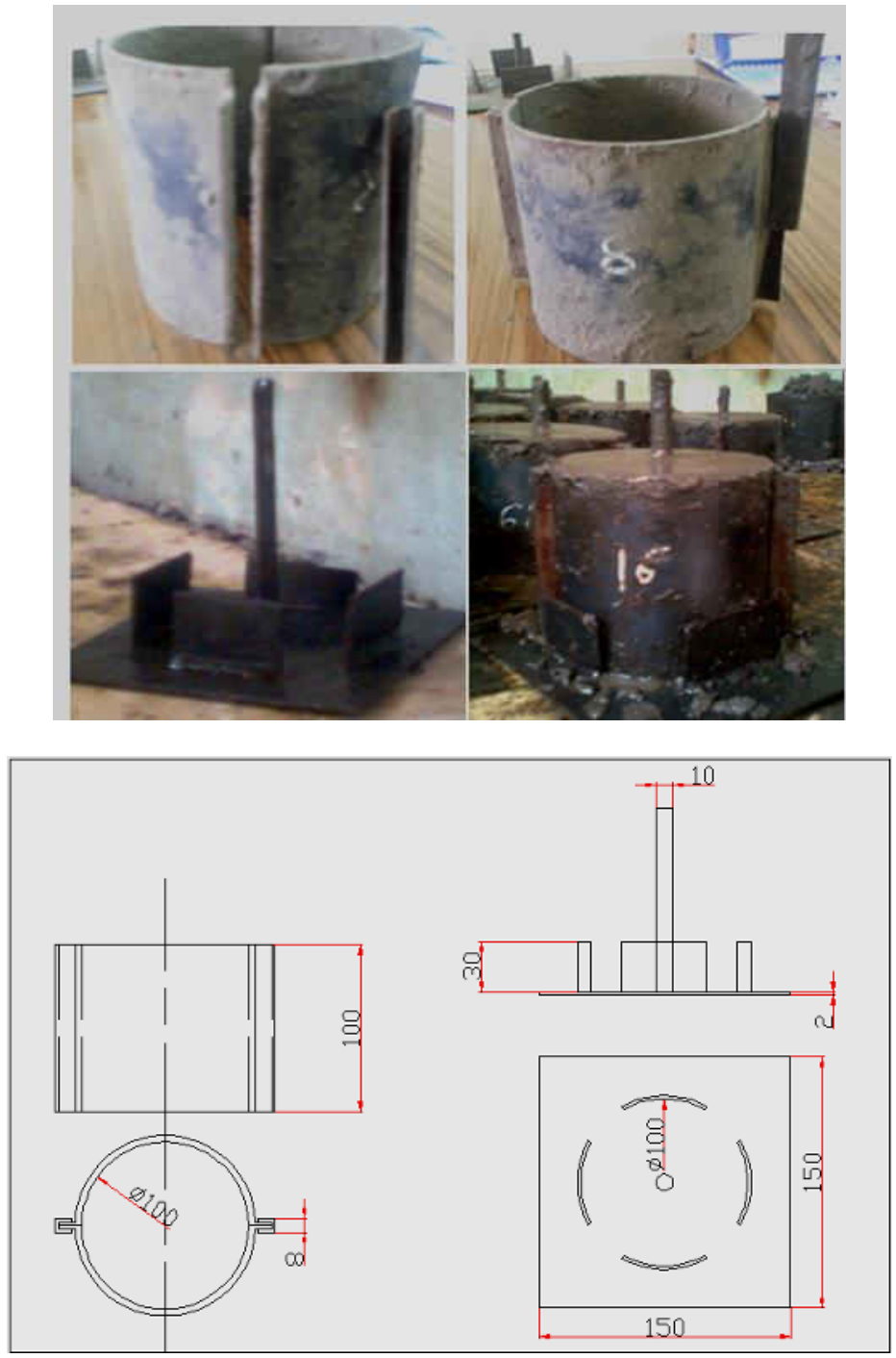

Fig. 5. The mold, centric bar, and the sample during preparation

- The center hole is widened to $12 \mathrm{~mm}$ using drill to take the epoxy adhesive around the steel bar. The hole was cleaned using compressed air then the epoxy mixture is poured into the hole.

- The steel threaded bolt is inserted into the hole and moved in / out to several times to ensure good distribution of the epoxy [18-20].

Journal of Engineering Sciences, Assiut University, Faculty of Engineering, Vol. 41, No. 4, July, 2013,E-mail address: jes@aun.edu.eg 
SH. M. Ismael, et al., Characteristic of anchor embedded on concrete under different loading rate, pp. $1564-1580$

- The embedded length of the steel rod is adjusted using plastic clamp on the steel rod and by filling the rest of the hole length by a piece of foam to prevent the rod from going deeper in the hole.

- The steel rod remaining length is to be chipped of to keep only $2.5 \mathrm{~cm}$ of its free length to prevent buckling of the steel rod during tests Fig.6.

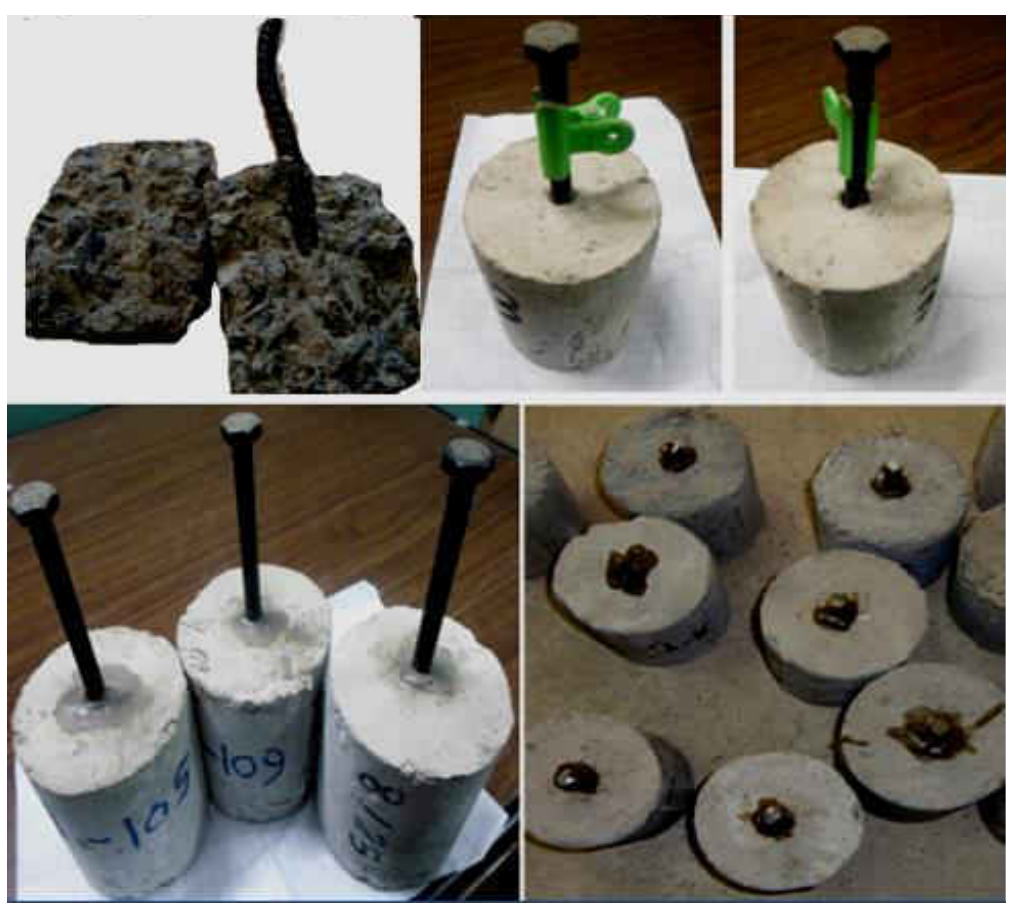

Fig. 6. Samples after preparations

\section{Experimental procedure}

Experiments were carried out on a $1000 \mathrm{kN}$ universal testing machine, Tinios Olsen Machine Model 290 Display Fig.7 equipped with a data acquisition device [21]. Data acquisition was performed using a system composed of computer, data acquisition card and application software, which performs the A/D conversion. The relationship between load and overhead stroke is plotted and displayed directly on screen and saved on Excel work sheet for later manipulation. The overhead of $1.15 \mathrm{~mm} / \mathrm{sec}$ was considered to be quasi static speed.

Journal of Engineering Sciences, Assiut University, Faculty of Engineering, Vol. 41, No. 4, July, 2013,E-mail address: jes@aun.edu.eg 
SH. M. Ismael, et al., Characteristic of anchor embedded on concrete under different loading rate, pp. $1564-1580$
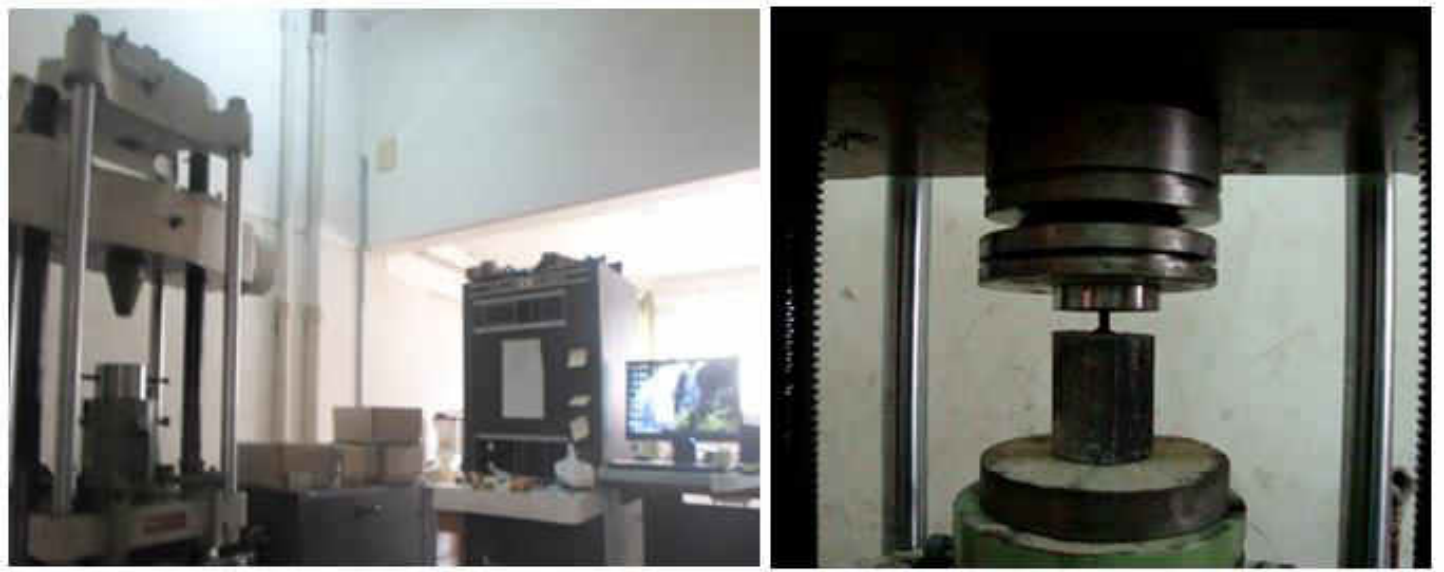

Fig. 7. Tinios Olsen Machine Model 290 Display

For dynamic loading Hopkinson split pressure bar is the only test apparatus that can cover the range of dynamic loading that need to be studied with adequate accuracy, because of the nature of its measuring system that eliminate stress wave superposition opportunity[22 and 23]. A compressive stress wave is generated and then propagates towards the specimen, moving the bar material towards the specimen as it sweeps by. When the wave arrives at the interface between the incident bar and the specimen, part of the wave is reflected back into the incident bar towards the impact end and the rest transmits through the specimen into the transmission bar. Laboratory instrumentation shown in Fig.8 [24 and 25] can record the stress waves in the incident bar propagating towards the specimen and being reflected back from the specimen and the wave in the transmission bar. Under this arrangement the impact event is controllable and quantitative. The impact velocity and specimen size may be varied to achieve different strain rates. Further analysis on the waves recorded in the impact event results in information regarding the loading conditions and deformation states in the specimen. In this work a cylindrical concrete specimen with centered through hole in which an anchor installed in it using epoxy for fitting is investigated.

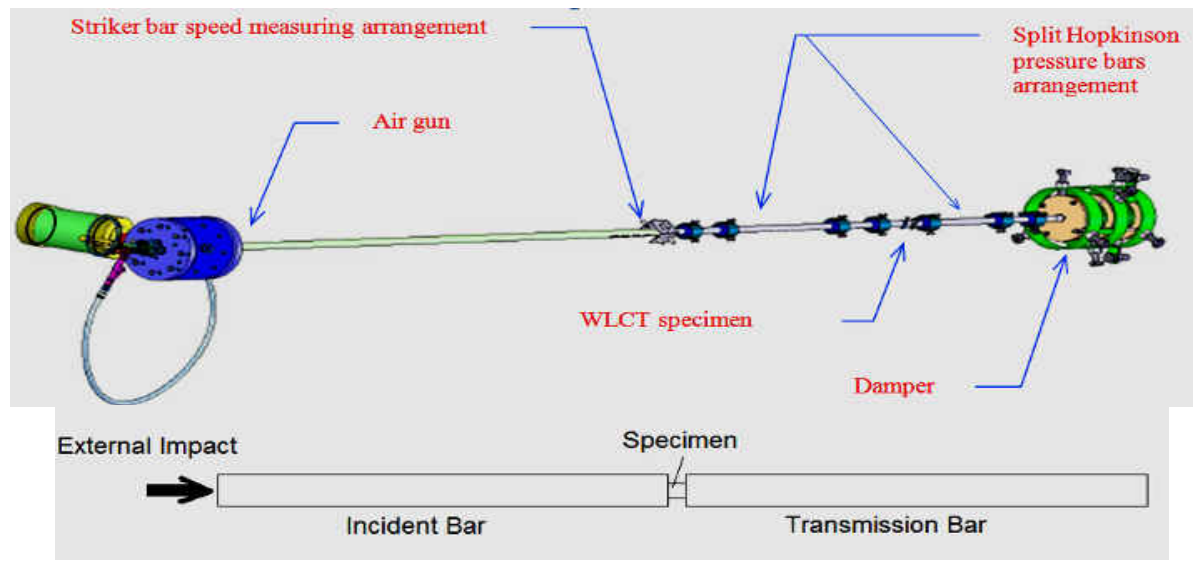

Fig. 8. Split Hopkinson pressure bar

Journal of Engineering Sciences, Assiut University, Faculty of Engineering, Vol. 41, No. 4, July, 2013, E-mail address: jes@aun.edu.eg 
SH. M. Ismael, et al., Characteristic of anchor embedded on concrete under different loading rate, pp. $1564-1580$

The experimentally obtained relation between air gun pressure and striker bar velocity are shown in Fig.11 [26] the stress waves in the incident bar (incident and reflected) are monitored using strain gage station mounted at the middle of the bar. The transmitted bar is 1.5 meter long and used to support the back of the specimen.

The strain gauge stations attached to the incident and transmitted bars record three strain gauge signals namely $\varepsilon_{i}(t), \varepsilon_{r}(t)$ and $\varepsilon_{t}(t)$ which are the incident, the reflected and the transmitted strain waves respectively

By knowing the distance between the strain gauge station and specimen it is possible to calculate the time of beginning of each signal. The net displacement of the specimen can then be determined as:

$$
\delta(t)=\mu_{I}(t)-\mu_{T}(t)=C_{O} \int_{0}^{t}\left(\varepsilon_{I}(t)-\varepsilon_{R}(t)-\varepsilon_{T}(t)\right) d t
$$

Where

$\mathrm{C}_{0}$ is the elastic wave speed in the Hopkinson bars materials $=\sqrt{\frac{E}{\rho}}$

E is the Young modulus of the incident and transmitted bar material.

$\rho \quad$ Is the bars material density.

Dimensional theory of elastic wave propagation as:

$\overline{P_{I}}(t)=\sigma_{I} \mathrm{~A}=\mathrm{EA}\left[\varepsilon_{I}(t)+\varepsilon_{R}(t)\right]$ and $\overline{P_{T}}(t)=\sigma_{T} \mathrm{~A}=\mathrm{EA} \varepsilon_{T}(t)$

And their average is:

$$
\bar{P}(t)=\frac{1}{2} E A\left[\varepsilon_{i}(t)+\varepsilon_{r}(t)+\varepsilon_{t}(t)\right]
$$

Where:

A. Is the cross section area of the bars

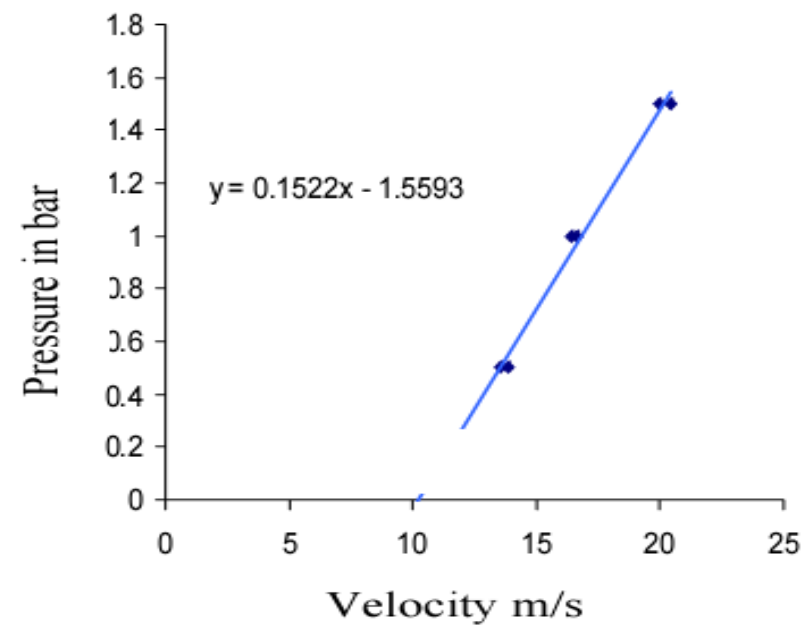

Fig. 9. The relation between air gun pressure and the striker bar speed

Journal of Engineering Sciences, Assiut University, Faculty of Engineering, Vol. 41, No. 4, July, 2013,E-mail address: jes@aun.edu.eg 
SH. M. Ismael, et al., Characteristic of anchor embedded on concrete under different loading rate, pp. $1564-1580$

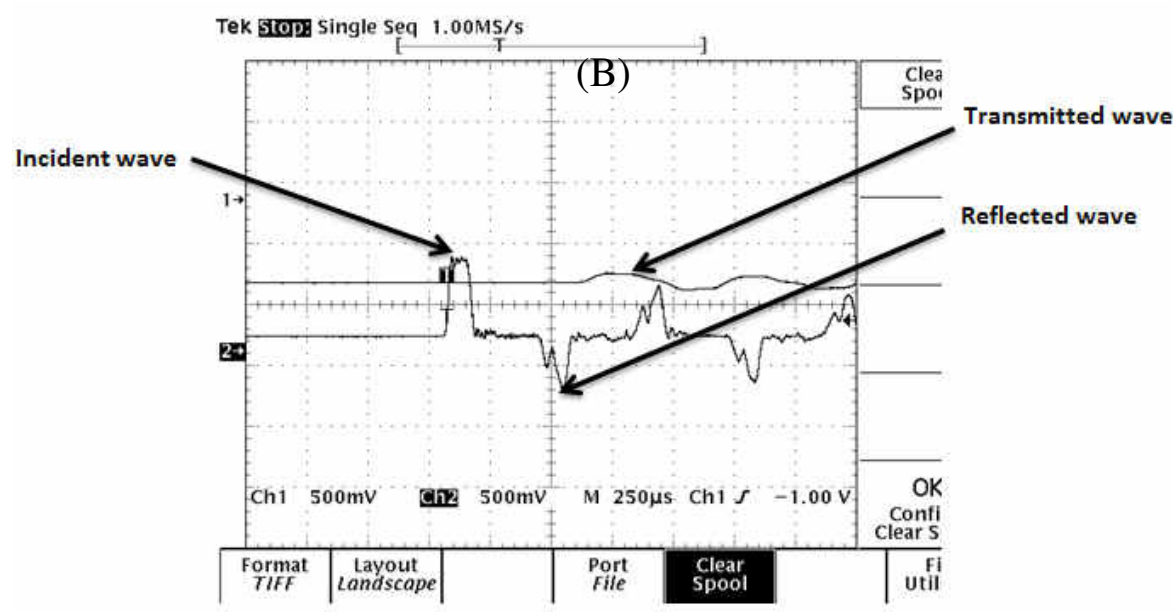

Fig. 10. power supply photographed

The system shown in Fig.11 consists of:

- Specially built three channel amplifier with built in 12 DC volt power supply as clearly photographed and shown in Fig.10[27].

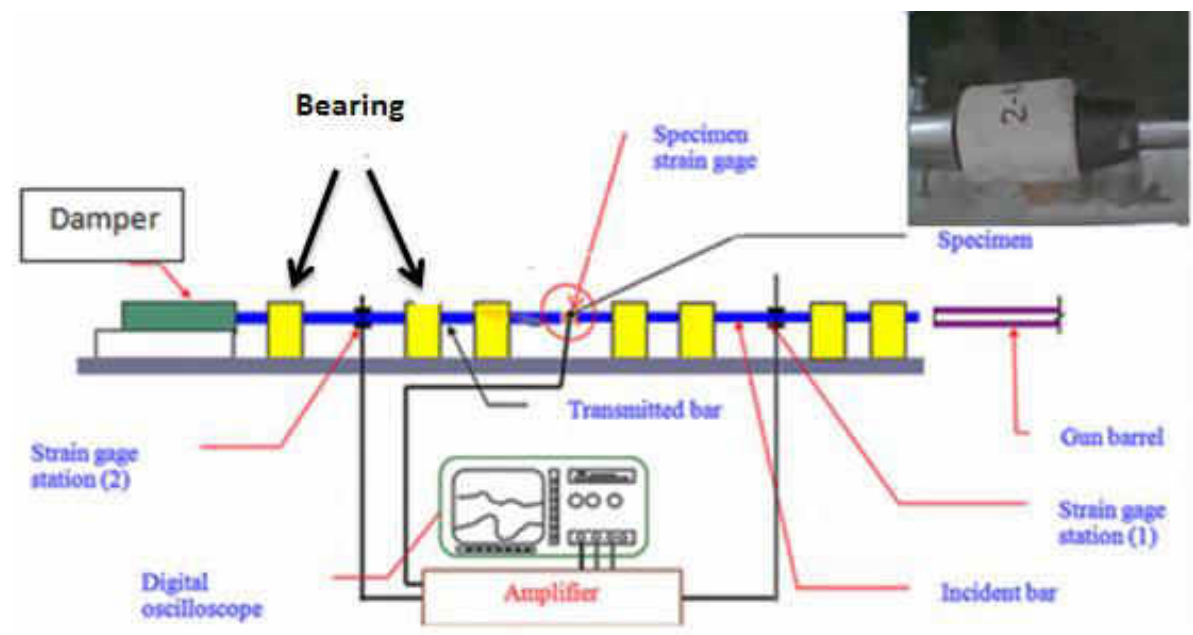

Fig. 2. Split Hopkinson pressure bar measuring system

- Digital oscilloscope with memory TDS-420A (Tektronix $200 \mathrm{MHz}$ maximum analog bandwidth; 100Mega-sample /second digitizing rate; 4 channels; attached floppy drive $1.44 \mathrm{MB})$.

Journal of Engineering Sciences, Assiut University, Faculty of Engineering, Vol. 41, No. 4, July, 2013,E-mail address: jes@aun.edu.eg 
SH. M. Ismael, et al., Characteristic of anchor embedded on concrete under different loading rate, pp. $1564-1580$

\section{Results and discussions}

The results obtained were classified into quasi static and dynamic results.

\section{1. Static results}

Several specimens were tested with embedded lengths of 2.5 and $5 \mathrm{~cm}$ with different types of concrete specimens which have Failure stress $(\sigma \mathrm{c})$ of $231,311 \mathrm{and} 180 \mathrm{~kg} / \mathrm{cm} 2$, under static load. The load and displacement curve for each of the tested specimen with different embedded length is shown in Fig. 12.
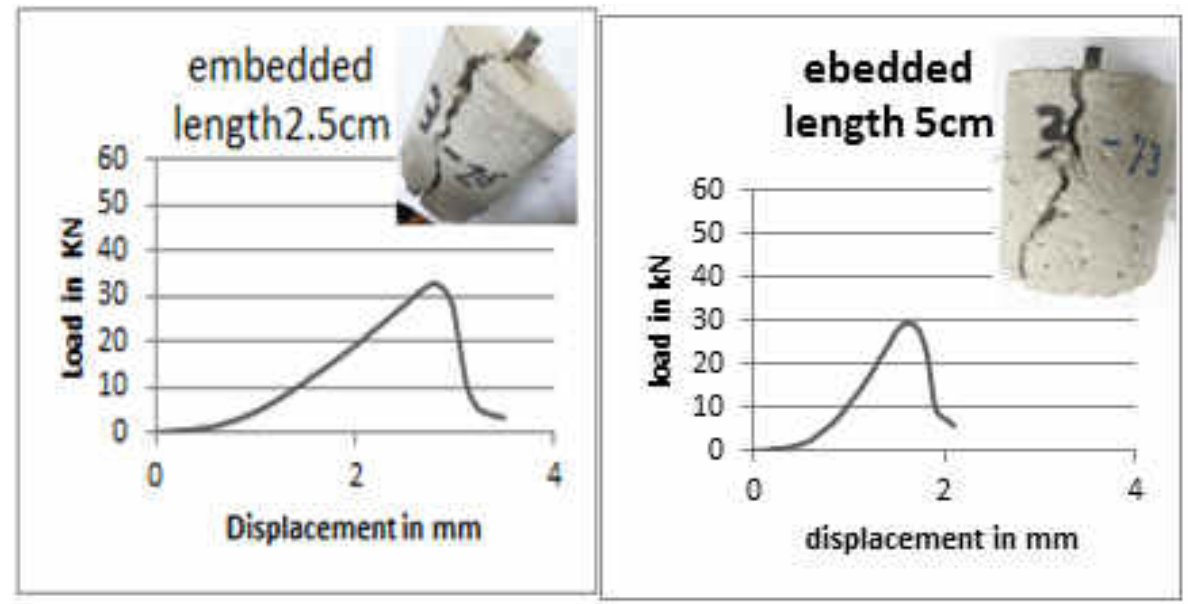

Fig. 3. Load displacement curve under different embedded length

For small embedded length $(2.5 \mathrm{~cm})$ the bar subjected to little tiling because the epoxy is not enough to sustain linearity of loading when loading the anchor, the anchor collide with the hole wall which support the anchor increasing the loading capacity of the system.

While in case of deep embedded length $(5 \mathrm{~cm})$ the epoxy ensure the straightness of the bar and the whole load is carried by the week epoxy layers which fall at the lower load than the previous case.

Effect of different types of concrete on failure load is shown in Fig.13.

For the specimen with strength of $185 \mathrm{~kg} / \mathrm{cm} 2$ the failure load occurs after displacement of $3.5 \mathrm{~mm}$ which is the highest displacement through other specimens, while the stronger specimen has shorter displacement. This is due to low cement quantity that weakens the sample which in turn minimizes the progress of the crack. The crack behavior was random because of the un homogeny of concrete matrix.

Journal of Engineering Sciences, Assiut University, Faculty of Engineering, Vol. 41, No. 4, July, 2013,E-mail address: jes@aun.edu.eg 
SH. M. Ismael, et al., Characteristic of anchor embedded on concrete under different loading rate, pp. $1564-1580$

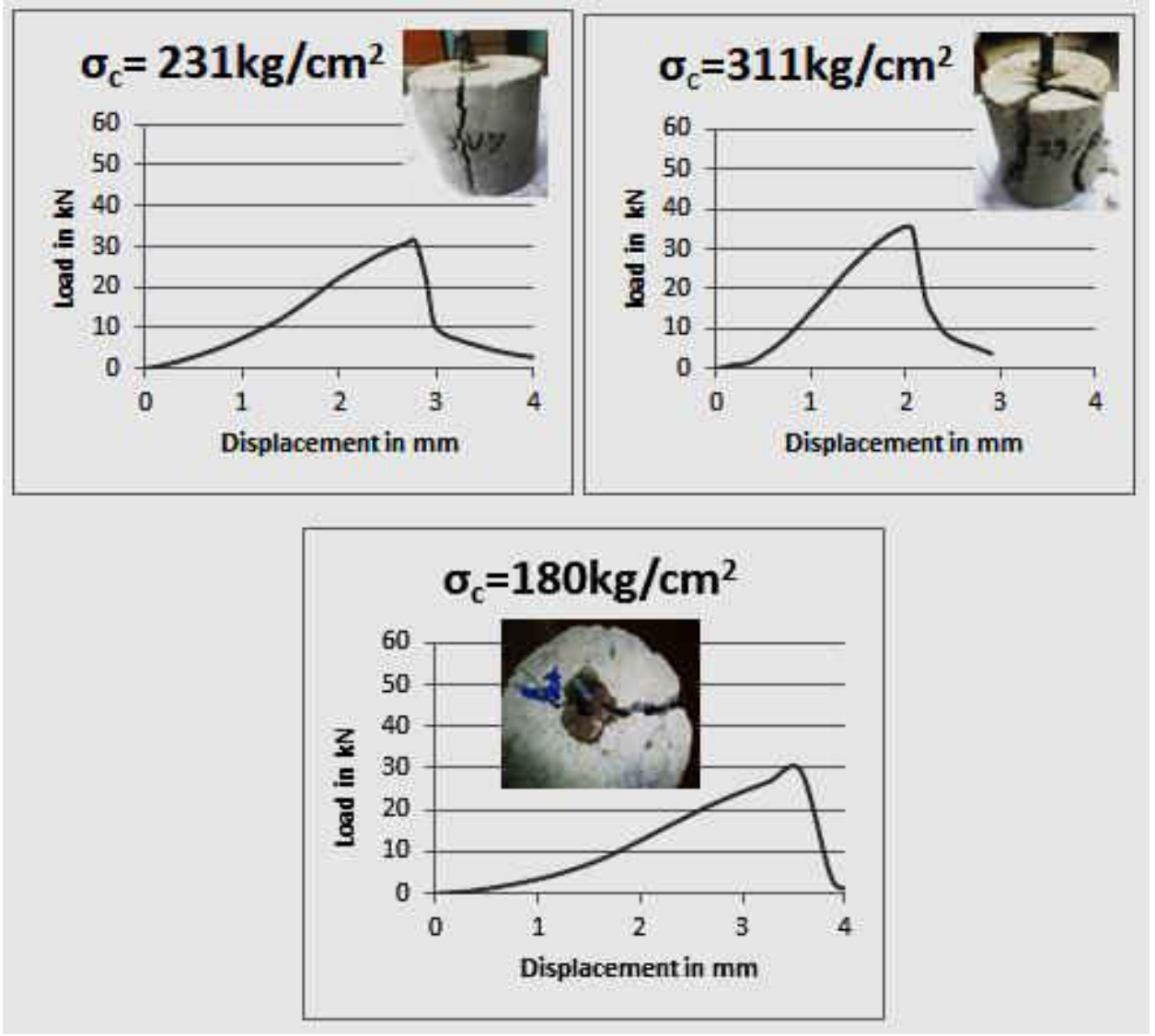

Fig. 4. Load displacement curve under different type of concrete

\section{2. Dynamic results}

Several specimens were tested with embedded lengths of 2.5 and $5 \mathrm{~cm}$ under air pressure of 1 and 1.5 bar that produce striker velocity of 17 and $20 \mathrm{~m} / \mathrm{sec}$ respectively [28 and 29]. The specimen is centrally positioned between the incident and transmitted bars. The specimen is then subjected to the stress wave produced from hitting the incident bar by a $23 \mathrm{~cm}$ striker bar. The incident, reflected and transmitted stress wave were recorded during the test using strain gauge stations on the incident and reflected bar that converted into load and displacement curves using equations 1 and 3 respectively. The load and displacement curves for each of the tested specimens with the fractured specimens' photography are shown in Figs.14and 15.

The effect of dynamic speed on the failure load is shown in Figs.14 and 15. [30] in which the more kinetic energy causes high deformation and then distorts the specimen.

Journal of Engineering Sciences, Assiut University, Faculty of Engineering, Vol. 41, No. 4, July, 2013,E-mail address: jes@aun.edu.eg 
SH. M. Ismael, et al., Characteristic of anchor embedded on concrete under different loading rate, pp. $1564-1580$
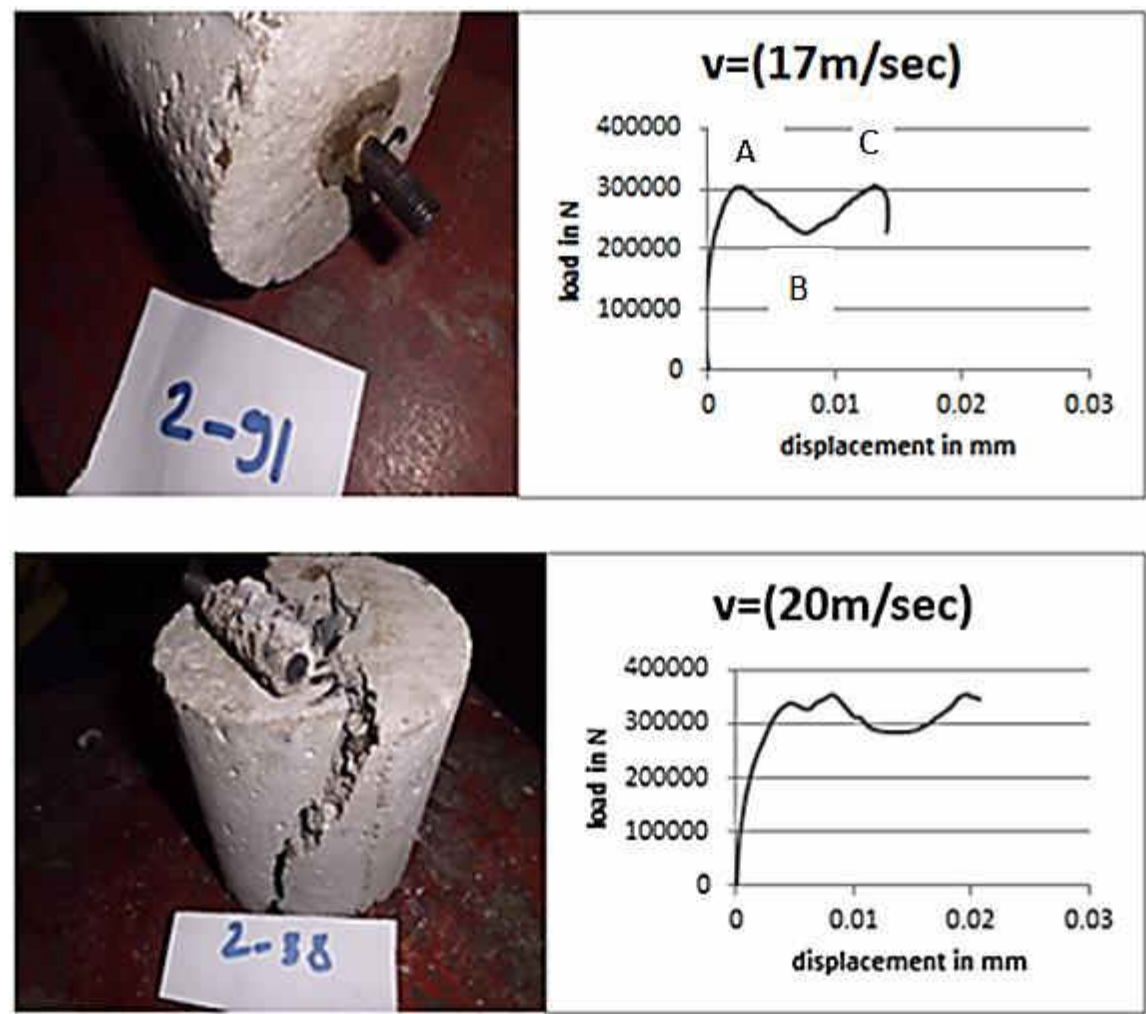

Fig. 5. Load displacement curve for different striker velocity for embedded length $2.5 \mathrm{~cm}$
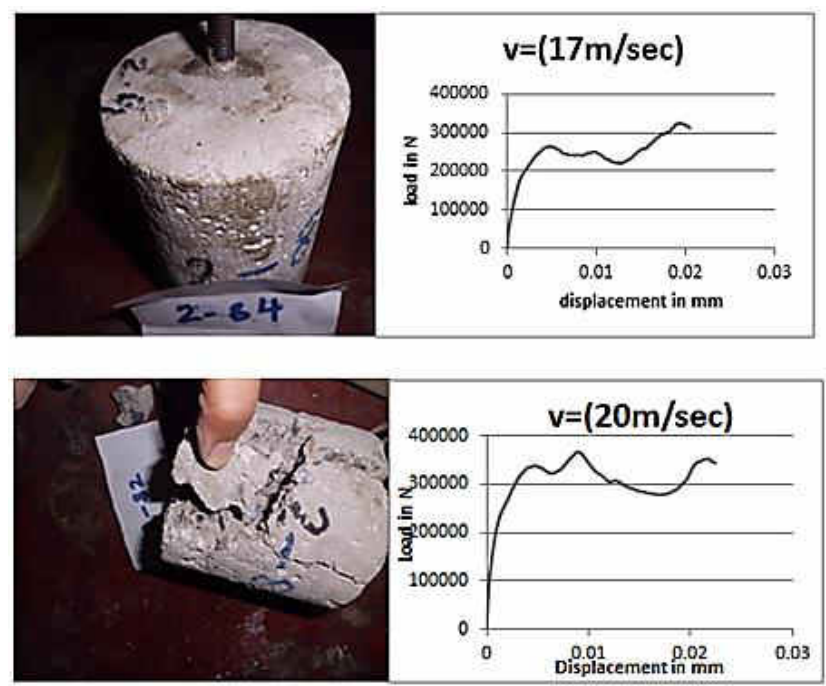

Fig. 6. Load displacement curve for different striker velocity for embedded length $5 \mathrm{~cm}$

Journal of Engineering Sciences, Assiut University, Faculty of Engineering, Vol. 41, No. 4, July, 2013,E-mail address: jes@aun.edu.eg 
SH. M. Ismael, et al., Characteristic of anchor embedded on concrete under different loading rate, pp. $1564-1580$

The scenario of failure can be recognized from the analysis of load-displacement curves of the tested specimens. The shock wave transferred from the anchor steel bar to the epoxy layer which deliver it to the concrete hole wall as shown in Fig. 16.

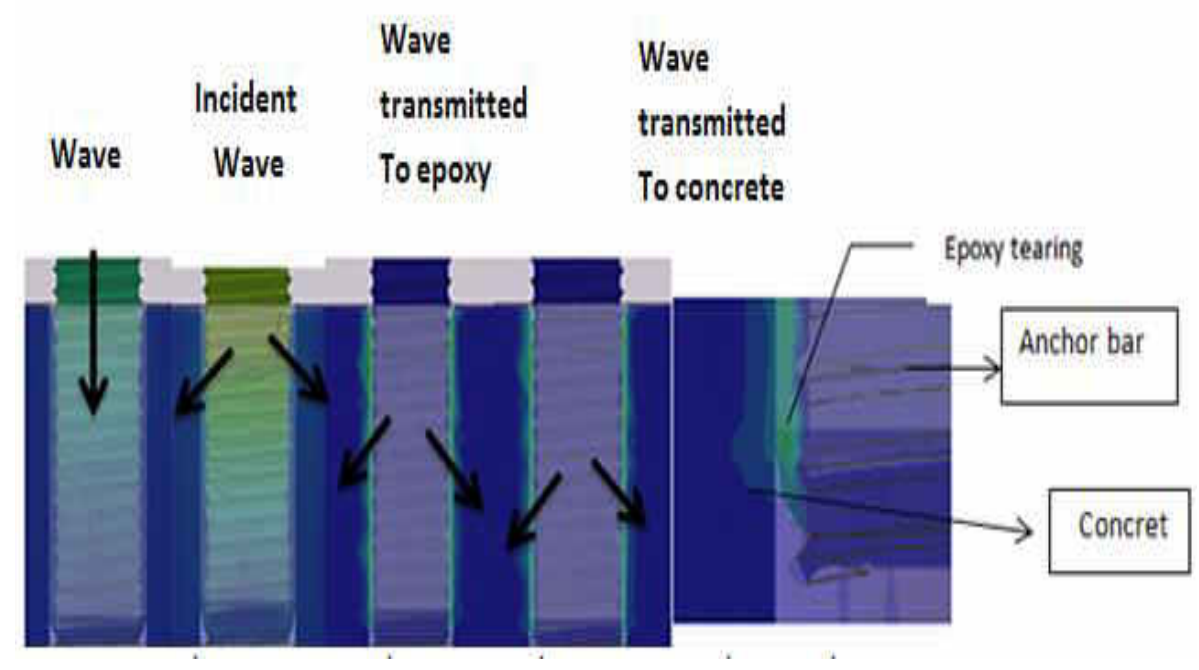

Fig. 7. Wave propagation through specimen and epoxy tearing mechanism

As the adhesive layer elastically deformed and direct contact occur between the steel bar and concrete causing excessive loading to transfer as shown in Fig.14point (A) where max load before adhesive joint begin to fail, the concrete began to crack then the epoxy layer turn apart as shown in Fig.14 point (B) and the steel bar began to drill deeper in the hole in a dynamic manner which can be recognized from analyzing the load displacement curve shown in Fig.14 point (C). However for small stress wave amplitude induced by air pressure of 1 bar was not enough to cause adhesive failure in most of the test. The adhesive layer absorbs the shock wave by tearing the week part of the adhesive layer however the rest of the joint remain unattached and the mechanical interlock prevent the anchor separate in from the joint. For the 1.5 bar the wave tear the adhesive joint and overcome the interlocking mechanism between the adhesive and concrete causing the wave to transfer to the concrete block. The concrete block cracked and sometime explodes into small parts releasing the anchor and destroying the joint completely. The area under the load displacement curve for each specimen was measured and the collective toughness data of the tested specimen drawn against the embedded length are shown in Fig.17 [31]. It is clear that as the embedded length of the anchor increases as the specimen decreases energy until failure. This strange trend indicates that the epoxy layer length increase will not increase the overall strength of the anchor. This is mainly due to the fact that the epoxy layer is the second item that the stress wave transfers to it after leaving the steel bar and the whole system inherit the characteristic of the epoxy layer which is the weakest between the three components of the anchor system composed from. So by increasing the epoxy length

Journal of Engineering Sciences, Assiut University, Faculty of Engineering, Vol. 41, No. 4, July, 2013,E-mail address: jes@aun.edu.eg 
SH. M. Ismael, et al., Characteristic of anchor embedded on concrete under different loading rate, pp. $1564-1580$

the whole system become weaker at higher loading rates. While at static loading conditions the anchor system become stronger as the epoxy layer length increase. The optimum anchor design concluded from this relation is to produce anchor with changeable diameter where epoxy cover parts of the embedded length of the anchor while the other parts are directly in contact with concrete to transfer the load directly to the concrete in case of dynamic loading.

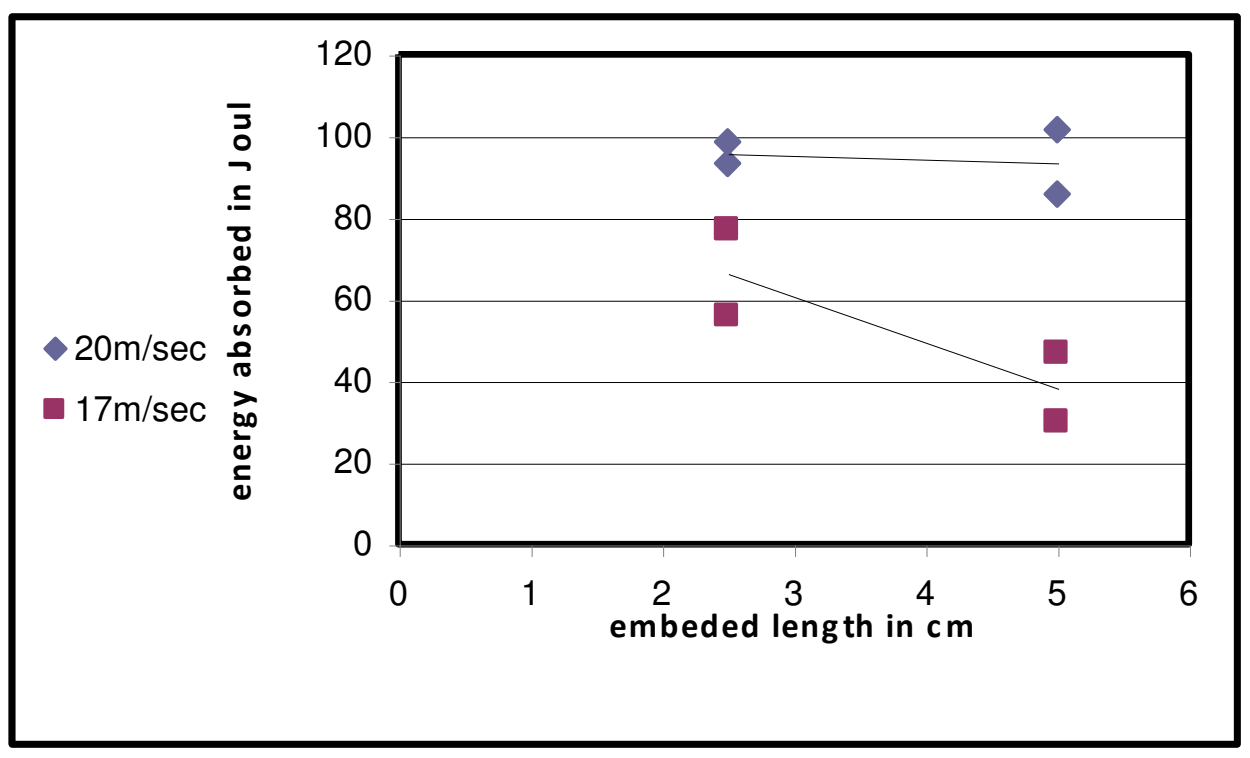

Fig. 8. Relation between embedded length and energy absorbed

\section{Conclusions}

1. A small embedded length of anchor increasing the loading capacity of the system.

2. The low cement quantity weakens the sample which in turn minimizes the progress of the crack. The crack behavior was random because of the non homogeny of concrete matrix.

3. The effect of dynamic speed on the failure load, the more kinetic energy cause high deformation and then distorts the specimen, the increase of the velocity of striker bar decrease the wave transmits to the concrete part of the specimen causing rupture or cracking of this part.

\section{References}

[1] G.S. Duffo , M. Reinoso , C.P. Ramos and S.B. Farina, "Characterization of steel rebars embedded in a 70-year old concrete structure" , Cement and Concrete Research, vol.42 ,(2012). Pp. 111-117.

[2] C. Gadve, A. Mukherjee and S.N. Malhotra, "Corrosion of steel reinforcements embedded in FRP wrapped concrete", Construction and Building Materials, vol.23, (2009). Pp. 153-161.

Journal of Engineering Sciences, Assiut University, Faculty of Engineering, Vol. 41, No. 4, July, 2013, E-mail address: jes@aun.edu.eg 
SH. M. Ismael, et al., Characteristic of anchor embedded on concrete under different loading rate, pp. $1564-1580$

[3] A. I. Al-Negheimish and R. Z. Al-Zaid, "Effect of manufacturing process and rusting on the bond behavior of deformed bars in concrete", Cement \& Concrete Composites, vol.26, (2004). Pp. 735-742.

[4] I. Kishimoto, "Experimental study on the corrosion condition of steel barsin cracked reinforced concrete specimen", International Symposium on the Ageing Management \& Maintenance of Nuclear Power Plants, Japan, (2010). pp.166-172

[5] C. A. Issa and P. Debs, "Experimental study of epoxy repairing of cracks in concrete" Lebanon, Construction and Building Materials vol.21, (2007). Pp. 157-163.

[6] N. P. Mailvaganam and L. Mitchell, "Repairs to restore serviceability in concrete structures", Construction Technology Update No. 59, National Research Council of Canada, (2003), pp. 1206-1220.

[7] R. A. Cook ,E. P. Douglas and T. M. Davis Gainesville, "Adhesive anchors in concrete under sustained loading conditions" "NCHRP" National Cooperative Highway Research Program report 639", University OF Florida Gainesville, FL, Washington, D.C.2009

[8] D. O. AL- Ghamdy, "Strength and durability of adhesive anchor bolts", Saudi Arabia, JKA U: Eng. Sci.., vol. 6, (1994) pp. 99- 113

[9] L. De Lorenzis , A. Rizzo and A. La Tegola , "A modified pull-out test for bond of nearsurface mounted FRP rods in concrete", Elsevier Science Ltd Composites: Part B 33 (2002). pp. 589-603.

[10] R.Vuletic and P.E., "Torque-controlled adhesive anchors an introduction to a new type of post-installed anchor", Structure Magazine (2008), pp. (22-23).

[11] D. F.Meinheit,P.E., S.E.,R.E. Wollmershausew, P.E.,FACI and J. E.pearson, P.E., S.E., "Bonded anchors a convenient solution or potential liability", Structure Magazine, (2007), pp. (50-51)

[12] "Calculating anchor bolt pullout strength", Calculating Pull-Out Strength Bulletin No. 691B, (2005), pp. (1-2), equipment foundation systems.

[13] M. A. El-Reedy, "Construction management and design of industrial concrete and steel structures", Ph.D., Cairo, Egypt, 2011

[14] J. M. Baker, P.J. Nixon, A.J. Majumdar and H. Davies "Durability of building materials and components", London · New York · Tokyo · Melbourne · Madras, 1991.

[15] E. M. Petrie, "Epoxy adhesive formulations", McGraw-Hill, 2006

[16] D. Ratna, " Epoxy composites: impact resistance and flame retardancy ", Vol. 16, No 5, 2005.

[17] C. Liu and J. Huang, "Highly flowable reactive powder mortar as a repair material", Taiwan, Construction and Building Materials, vol. 22 (2008), pp. 1043-1050

[18] K., Y. Cheng, K. Pei and M. Shah, "Fatique failure of concrete beam rep aired with epoxy", Chaoyang University of Technology in Taiwan, the grant number NSC94-2211-E324-015.

[19] W.M. A. Elleithy, "Bond and durability of fusion-bonded epoxy-coated steel bars", Master of science, college of graduate studies King Fahd University of Petroleum \& Minerals Dhahran, Saudi Arabia, June, 1995.

[20] S. Jorge, D. Dias-da-Costa and E.N.B.S. Julio, "Influence of anti-corrosive coatings on the bond of steel rebars to repair mortars", Portugal, Engineering Structures vol.36, (2012), pp. 372-378.

[21] C.S. Chen, C.S. Lim, "dynamic and static load tests on diameter bored piles", Associate Director, SSP Geotecnics Sdn bhd, Level 6, Wisma SSP, No.1, Jalan SR 8/3, Serdang Raya Seksyen8, 43300 Seri Kembangan, Selangor, Malaysia.

[22] D. Zhu, A. Peled and B. Mobasher, " Dynamic tensile testing of fabric-cement composites", United States, Construction and Building Materials, vol.25, (2011), pp. 385-395.

[23] G. Solomos and M. Berra, "Rebar pullout testing under dynamic hopkinson bar induced impulsive loading", Italy, Materials and Structures (2010) 43:247-260, DOI $10.1617 / \mathrm{s} 11527-009-9485-\mathrm{z}$.

Journal of Engineering Sciences, Assiut University, Faculty of Engineering, Vol. 41, No. 4, July, 2013,E-mail address: jes@aun.edu.eg 
SH. M. Ismael, et al., Characteristic of anchor embedded on concrete under different loading rate,

pp. $1564-1580$

[24] W. M. Khair- Aldien , "Study of the fracture toughness of powdered manufactured aluminum matrix composites under different loading rates", Ph.D. thesis, Assiut University, Egypt ,May 2007

[25] J. Haines, C. Knight and R. Glaser "Design and characteristics of a split hopkinson pressure bar apparatus ", University Of Maine, Mechanical Engineering, 2007.

[26] H. Nishida and S. Unjoh, "Dynamic response characteristic of reinforced concrete column subjected to bilateral earthquake ground motions", 13th World Conference on Earthquake Engineering Vancouver, B.C., Canada Paper No. 576, August 1-6, 2004.

[27] W. W. Chen and B. Song, "Split Hopknson (Kolsky) bar design", Testing and Applications(2011), Springer New York Dordrecht Heidelberg London

[28] L. J. Malvar and J. E. Crawford, " Dynamic increase factors for steel reinforcing bars", Twenty-Eighth DDESB Seminar, Orlando, FL, August 98.

[29] J. Henry, "Investigation of bond slip between concrete and steel reinforcement under dynamic loading conditions ", Louisiana State University, Doctor of Philosophy, 2003.

[30] M. Rodriguez, B.S.C.E.," Behavior of anchors in uncracked concrete under static and dynamic tensile loading ", Master of science in engineering, University of Texas AT Austin, August 1995, NRC-03-92-05.

[31] A. Ansell, "Laboratory testing of a new type of energy absorbing rock bolt", Sweden, Tunnelling and Underground Space Technology, vol.20, (2005), pp.291-300.

\section{خصائص مسامير التبيث الملصوقة في الخرسانة تحت تأثير معدلات تحميل مختلفة}

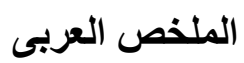

يدرس هذا البحث تأثير طول الجزئ الملصوق من مسامير التنبيت في الخرسانة علي الخصائص الميكانيكية

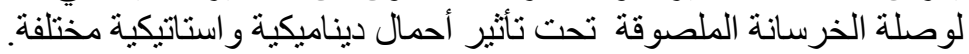

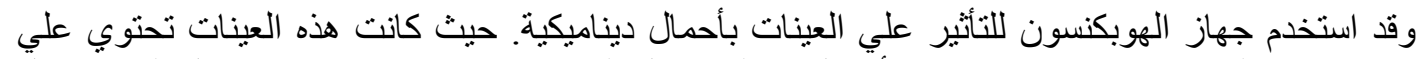

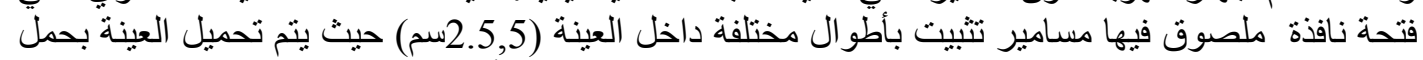

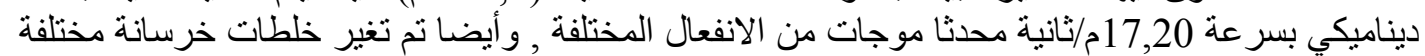

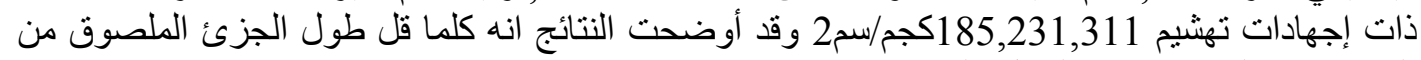
المسمار في الخرسانة زاد التهم الته الذي يحدث عنده الانهيار.

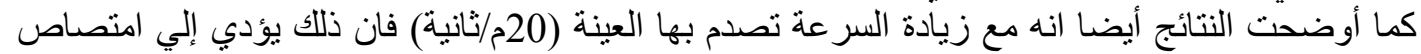

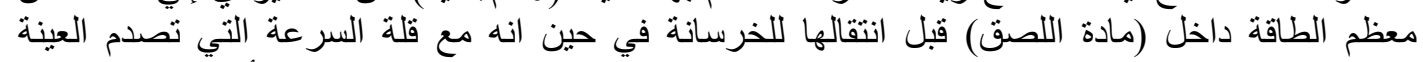
(17م/ثانية) فانه يكون هنالك فترة اكبر لانتقال الموجات إلي الخرسانة مؤديا إلي شروخ أو تهنيم كامل في الخرسانة.

Journal of Engineering Sciences, Assiut University, Faculty of Engineering, Vol. 41, No. 4, July, 2013,E-mail address: jes@aun.edu.eg 